\title{
ANAL YSIS OF RISK FACTORS ASSOCIATED WITH DIARRHEA IN WORK AREA HEALTH DISTRICT CHARMING CITY Sidomulyo PEKANBARU
}

\section{Chairil}

chairil@umri.ca.id

Staf pengajar Jurusan DIII Keperawatan FMIPA dan Kesehatan

\section{ABSTRACT}

Diarrhea is one of the diseases that get priority eradication program because of the high morbidity and caused many deaths. In an effort to decrease the morbidity due to diarrhea important to know the factors that become menyebab incidence of the disease include the state of the environment, disease vector, personal hygiene, snack habits, and health services. The research was done at Village West Sidomulyo Tuah Karya and Sidomulyo subdistrict Puskesmas Handsome that during the period of the last 4-6 months of diarrhea always get into the top 10 diseases. The research objective was to determine the relationship between risk factors with the incidence of diarrhea. The study was a cross sectional study, using a questionnaire. Sampling was done by random sampling, some 96 respondents. Results of research for the environmental health situation no association with diarrhea because of the test results chi-square statistic with continuity correction values obtained $p=(1.00)>$ $\alpha=(0.05)$, disease-carrying vector no association with diarrhea because of test results chi-square statistic with continuity correction values obtained $p=(1.00)>\alpha=(0.05)$, there is no relationship between personal hygiene with diarrhea, because of the results of statistical chi-square test with continuity correction values obtained $p=(0.69)>\alpha=(0.05)$, there was no relationship between snacks at roadside with diarrhea, because of the results of statistical chi-square test with continuity correction values obtained $p=(1.00)>\alpha=(0,05)$ there is no relationship between counseling with diarrhea, because of the results of statistical chi-square test with continuity correction values obtained $p=(0.42)>\alpha=(0.05)$, the variables being researched nothing to do with diarrhea, but it diskritif there, it is to note could be a risk for diarrhea will occur, it is necessary to promotive and preventive efforts

Keywords: diarrhea, personal hygiene, environmental sanitation, risk factors

\section{PENDAhUluAN}

Pembangunan kesehatan merupakan bagian integral dari pembangunan nasional, yaitu untuk tercapainya kemampuan hidup sehat bagi setiap penduduk agar dapat mewujudkan derajat kesehatan yang optimal. tujuan pembangunan kesehatan yang ditetapkan, yaitu pembangunan kesehatan bertujuan untuk meningkatkan kesadaran, kemauan dan kemampuan untuk hidup sehat bagi setiap orang agar mewujudkan derajat kesehatan masyarakat yang optimal (Depkes RI, 2003).

Terwujudnya keadaan sehat merupakan suatu keadaan yang sangat komplek yang saling berkaitan antara sektor kesehatan dengan sektor di luar kesehatan. Keadaan sehat tidak hanya menjadi tanggung jawab sektor kesehatan, melainkan juga sektor-sektor lain di luar kesehatan. Demikian pula dalam pemecahan masalah kesehatan di masyarakat tidak hanya dilihat dari sektor kesehatan saja, namun juga harus dilihat dari seluruh sektor yang ada pengaruhnya terhadap masalah kesehatan tersebut (Notoatmodjo, 2003).
Banyak faktor yang mempengaruhi kesehatan, baik kesehatan individu maupun kesehatan masyarakat. Untuk hal ini Hendrik L Bloom (1974) yang dikutip oleh Soekidjo Notoatmodjo menggambarkan secara ringkas sebagai berikut:

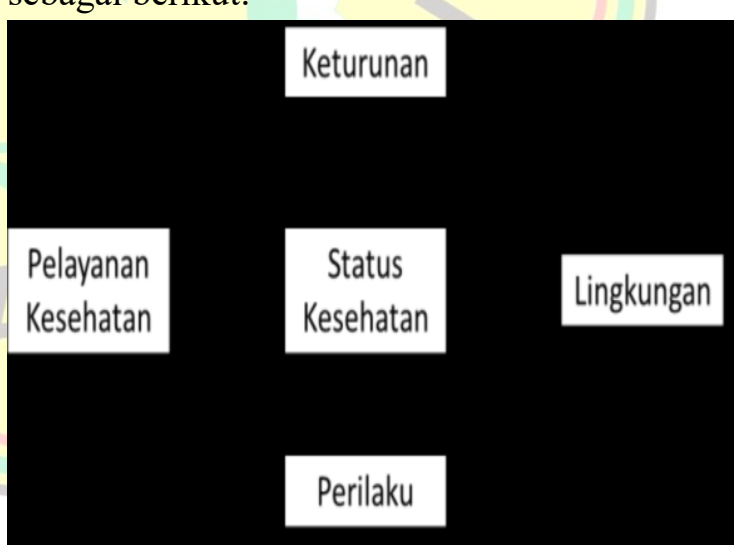

Gambar. 1. Faktor-faktor yang mempengaruhi kesehatan individu dan masyarakat menurut Hendrik L. Bloom (1974)

Lingkungan yang sehat adalah lingkungan yang kondusif bagi terwujudnya keadaan sehat, yaitu lingkungan yang bebas polusi, 
tersedianya air bersih, sanitasi lingkungan yang memadai, perumahan dan pemukiman sehat, perencanaan kawasan berwawasan kesehatan dan kehidupan masyarakat yang saling tolongmenolong. Pentingnya lingkungan yang sehat telah dibuktikan oleh WHO dengan penyelidikan-penyelidikan di seluruh dunia dimana didapatkan hasil bahwa angka kematian (Mortality), angka perbandingan orang sakit (Morbidity) yang tinggi serta sering terjadinya epidemik, terdapat pada tempattempat dimana terdapat kecoa, tikus, lalat, pembuangan kotoran sampah yang tidak teratur, sisa makanan yang ada di dalam rumah, pembuangan air rumah tangga yang tergenang, perumahan yang tidak sehat dan keadaan sosial ekonomi yang kurang baik. Sebaliknya di tempat-tempat dimana hygiene dan sanitasi lingkungan sehat, mortality menurun dan wabah berkurang dengan sendirinya.

Penyakit merupakan keadaan dengan bentuk dan fungsi tubuh mengalami gangguan sehingga berada dalam keadaan tidak normal. Timbul atau tidaknya penyakit dipengaruhi oleh tiga faktor, yaitu: penyebab penyakit (agent), penjamu (host), dan lingkungan. Penyakit terjadi apabila ada gangguan keseimbangan antara ketiga faktor tersebut. Usaha kesehatan masyarakat ditujukan untuk mengendalikan keseimbangan dari ketiga faktor sehingga masyarakat dapat mencapai kesehatan setinggi-tingginya (Berita kedokteran Masyarakat vol 23 no 3 September 2007).

Satu diantara penyakit yang ada hubungannya dengan lingkungan adalah diare, diare merupakan keadaan dimana seseorang mengalami keadaan, tinjanya encer dengan frekuensi 4-6 kali sehari, dapat bercampur darah dan lendir kadang disertai muntahmuntah. Hal ini dapat menyebabkan cairan tubuh berkurang. Bila penderita diare mengalami kehilangan cairan tubuh, maka hal ini dapat menyebabkan kematian terutama pada bayi dan anak-anak usia di bawah lima tahun. Angka kejadian diare di sebagian besar wilayah Indonesia hingga saat ini masih tinggi (Kuntari, 2008).
Data Departemen Kesehatan RI menunjukkan 5.051 kasus diare sepanjang tahun 2005 lalu di 12 Provinsi. Jumlah ini meningkat drastis dibandingkan dengan jumlah pasien diare pada tahun sebelumnya, yaitu sebanyak 1.436 orang. Di awal tahun 2006, tercatat 2.159 orang di Jakarta yang dirawat di rumah sakit akibat menderita diare. Dari data tersebut dan kenyataan bahwa masih banyak kasus diare yang tidak terlaporkan, Departemen Kesehatan menganggap diare merupakan isu prioritas kesehatan di tingkat lokal dan nasional karena punya dampak besar pada kesehatan masyarakat (Depkes RI, 2008).

Data dari Dinas Kesehatan Kota Pekanbaru menunjukan diare merupakan penyakit yang paling tinggi insidennya. Untuk penyakit berbasis Puskesmas Bulan Maret berjumlah 926 penderita yang terbagi menurut usia, umur 8-28 hari sebanyak 4 orang, umur $<1$ tahun sebanyak 118, umur 1-4 tahun sebanyak 253

orang, umur 5-9 sebanyak 98 orang, usia 10-14 sebanyak 83 orang, usia 15-19tahun sebanyak 87 orang, usia 20-44 tahun sebanyak 135 orang, usia 45-54 tahunsebanyak 64 orang, usia 55-59 tahun sebanyak 15 orang, usia 60-69 tahun sebanyak 19 orang, dan pada usia $70 \mathrm{ke}$ atas sebanyak 5 orang, dimana terbagi atas lakilaki 457 orang dan perempuan 469 orang (Dinas Kesehatan Kota Pekanbaru, 2010).

Hasil Surveilence Puskesmas Sidomulyo dari bulan April - Agutus 2010 didapatkan jumlah penderita diare 41 orang, dimana merupakan angka penyakit tertinggi. Penyakit ini diduga erat hubungannya dengan hygiene perorangan yang kurang baik, sanitasi lingkungan yang tidak sehat (misalnya penyediaan air bersih yang kurang memadai, pembuangan sampah dan kotoran yang kurang memenuhi syarat kesehatan, pengawasan makanan dan minuman yang belum sempurna).

Faktor yang ikut menyebabkan diare adalah hygiene dan sanitasi lingkungan.Keadaan lingkungan yang tidak sehat akan menjadi media penularan berbagai penyakit, salah satu diantaranya adalah diare, yang dibawa oleh kecoa, lalat dan tikus, karena mereka meninggalkan bakteri di setiap tempat 
ya ditinggalkannya. Kecoa, lalat, tikus, dikenal sebagai vektor. yang berperan dalam penyebaran penyakit dari hewan ke manusia (Nafika, 2008).Perilaku anak yang jajan sembarangan juga dapat menjadi faktor risiko terjadinya diare. FAO (Food and Agriculture Organisation) didefinisikan jajanan sembarangan sebagai makanan dan minuman yang dipersiapkan untuk dijual oleh pedagang kaki lima di jalanan dan di tempat-tempat keramaian umum lain yang langsung dimakan tanpa pengolahan atau persiapan lebih lanjut (Iswaranti, 2007).

Puskesmas Sidomulyo yang berlokasi di Panam merupakan kawasan rawan banjir bila hujan, data dari Dinas kesehatan kota Pekanbaru menyebutkan Pusekesmas Sidomulyo termasuk 10 besar yang tertinggi kunjungan pasien dengan diare. Hasil survey awal di lapangan pada tanggal 6 Juli 2010 Di Wilayah Puskesmas Sidomulyo didapatkan bahwa lingkungan tidak sehat, rawan banjir, sumber saluran air tidak lancar atau drainase tidak lancar, keadaan sampah yang menumpuk bila hujan, angka kunjungan pasien yang dominan menderita diare. Berdasarkan latar belakang di atas perlu dianalisis faktor-faktor risiko yang berhubungan dengan kejadian diare.

Rumusan MasalahBerdasarkan uraian tersebut perumusan masalah pada penelitian ini perlu dianalisis faktor-faktor risiko yang berhubungan dengan kejadian diare di Wilayah Kerja Puskesmas Sidomulyo Kecamatan Tampan Kota Pekanbaru.

\section{METODOLOGI PENELITIAN}

Jenis penelitian yang di gunakan adalah penelitian analitik, dengan desain yaitu penelitian cross sectional untuk mempelajari hubungan antara diare dengan faktor-faktor risiko.Penelitian ini dilaksanakan pada bulan Juli hingga Agustus 2015 di Puskesmas Sidomulyo Kecamatan Tampan Kota Pekanbaru.Populasi dari penelitian ini adalah masyarakat yang ada wilayah kerja Puskesmas Sidomulyo Kecamatan Tampan Kota Pekanbaru yang berjumlah 2481 orang.

Teknik pengambilan sampel dalam penelitian ini diambil dengan random sampling, yaitu pengambilan sampel secara acak.

Tabel 1 Jumlah Sampel pada Masingmasing Kelurahan di Wilayah Kerja Puskesmas Sidomulyo Kecamatan Tampan Kota Pekanbaru.

\begin{tabular}{|c|c|c|}
\hline No Kelurahan & $\begin{array}{l}\text { Jumlah } \\
\text { Populasi }\end{array}$ & Jumlah Sampel \\
\hline 1. Tuan Karya & 1281 & 50 \\
\hline 2. $\begin{array}{c}\text { Sidomulyo } \\
\text { Barat }\end{array}$ & 1201 & 46 \\
\hline Jumlah & 2481 & 96 \\
\hline
\end{tabular}

Sumber: Puskesmas Sidomulyo Kec Tampan Kota Pekanbaru.

Jadi sampel yang dibutuhkan sebanyak 96 Sampel.

a. Kriteria sampel.

1) Kriteria Inklusi :

a). Bersedia menjadi responden

b).Terdata di wilayah kerja puskesmas

c). Berusia minimal 10 Tahun.

d). Responden bisa baca tulis

Kriteria Eksklusi :

Subjek yang tidak layak untuk diteliti menjadi sampel sebagai berikut :

a) Mengalami penyakit lain.

b) Saat penelitian tidak ada di tempat

\section{Teknik Pengumpulan Data}

Pengumpulan data peneliti menggunakan data primer diperoleh dengan menyebarkan kuesioner kepada responden di wilayah Puskesmas .Data Sekunder Pengumpulan data dengan menggunakan data sekunder yaitu memperoleh melalui studi pustaka yaitu bukubuku yang berkaitan dengan masalah yang diteliti serta data lain yang mendukung dokumentasi yang diperoleh peneliti dari Puskesmas.

Data yang dikumpulkan diolah dengan langkah-langkah sebagai berikut:

\section{Editing}

Adalah dilakukan pengecekan kelengkapan data yang terkumpul, bila terdapat kesalahan atau kekurangan dalam pengumpulan data, dapat diperbaiki dengan memeriksa dan dilakukan pendataan ulang. CodingAdalah hasil jawaban dari setiap pertanyaan diberi 
kode dengan petunjuk.

\section{Tabulating.}

Tabulating adalah untuk mempermudah analisis data dimasukkan dalam bentuk tabel distribusi frekuensi. Instrumen dalam penelitian yang digunakan adalah kuesioner untuk mengukur usia, jenis kelamin, keadaan lingkungan, vektor pembawa penyakit, hygiene perorangan, perilaku kebiasaan jajan, dan pelayanan kesehatan.Data yang telah dikumpulkan, diolah, dan dianalisis dengan analisis univariat dan bivariat. Analisis UnivariatAnalisis ini dilakukan untuk menjelaskan atau mendeskripsikan karekteristik masing-masing variabel yang diteliti yaitu variabel independen dan variabel dependent dimana kedua variabel tersebut menggunakan skala ukur nominal.Analisis BivariatAnalisis ini digunakan untuk membuktikan hubungan yang bermakna atau tidak antara variabel independen maupun dependen. Uji statsti Untuk mengetahui tingkat kemaknaan hubungan variabel bebas (lingkungan ,vector pembawa penyakit, hygiene perorangan, perilaku kebiasaan jajan, pelayanan kesehatan ) terhadap variabel terikat (diere), dilakukan dengan uji chi square pada variabel bebas dan variabel terikat dengan data kategorikal.Tingkat kemaknaan hubungan antar variabel dilihat pada tingkat keyakinan $95 \%$ (alpha $=0,05)$. Artinya, apabila p-value hubungan suatu variabel $<0,05$ maka secara statistik hubungan tersebut bermakna atau perbedaan yang diberikan suatu variabel tidak disebabkan oleh faktor kebetulan. Dalam uji chi square ini juga memperhatikan seberapa kecenderungan perbedaan yang diberikan variabel bebas terhadap varibelabel terikat dengan melihat nilai odds ratio (OR) (Sutanto,2001)

Pertanyaan PenelitianDari rumusan masalah tersebut dapat diajukan beberapa pertanyaan penelitian, yaitu sebagai berikut :Apakah terdapat hubungan faktor risiko keadaan lingkungan dengan diare?Apakah terdapat hubungan faktor risiko keadaan vektor pembawa penyakit dengan diare?Apakah terdapat hubungan faktor risiko keadaan hygiene perorangan dengan diare?

Apakah terdapat hubungan faktor risiko perilaku kebiasaan jajan pada anak dengandiare?Apakah terdapat hubungan faktor risiko pelayanan kesehatan dengan diare?

Tujuan PeneliUntuk mengetahui faktorfaktor risiko yang berhubungan dengan kejadian diare di wilayah kerja Puskesmas Sidomulyo Kota Pekanbaru.Tujuan Khusus

Diketahuinya hubungan antara faktor keadaan lingkungan dengan diare di Wilayah Kerja Puskesmas Sidomulyo Kecamatan Tampan Kota Pekanbaru.

\section{HASIL DAN PEMBAHASAN}

\section{Karakteristik Responden}

Berdasarkan penelitian yang dilakukan pada bulan Juli-Agustus 2010 diperoleh data tentang karakteristik responden diwilayah kerja Puskesmas Kelurahan Sidomulyo Barat dan Tuah Karya Kec Tampan Kota Pekanbaru yang meliputi: umur, jenis kelamin, pendidikan terakhir dan pekerjaan.

\section{Berdasarkan penggolongan umur}

Penggolongan umur responden di Kelurahan Tuah Karya dan Sidomulyo Barat di Wilayah Puskesmas Kec Tampan Kota Pekanbaru

Tabel 2. Distribusi Frekuensi Umur Responden Kelurahan Tuah Karya dan Sidomulyo Barat di Wilayah Kerja Puskesmas Sidomulyo Kec Tampan Kota Pekanbaru Tahun 2010

\begin{tabular}{cccc}
\hline No & UMUR & JUMLAH & PERSENTAS\% \\
\hline 1 & $10-20$ & 3 & 3,12 \\
\hline 2 & $21-30$ & 17 & 17,70 \\
\hline 3 & $31-40$ & 33 & 34,37 \\
\hline 4 & $41-50$ & 20 & 20,83 \\
\hline 5 & $51-50$ & 16 & 16,66 \\
\hline 6 & $61-70$ & 4 & 4,16 \\
\hline 7 & $71-80$ & 3 & 3,12 \\
\hline & Jumlah & 96 & 100 \\
\hline
\end{tabular}

Berdasarkan Tabel 2 golongan umur terbanyak adalah berumur 31-40 tahun $(34,37 \%)$.

\section{Bersadarkan Penggolongan Pendidikan}

Penggolongan pendidikan respondendi Kelurahan Tuah Karya dan Sidomulyo Barat di 
Wilayah Puskesmas Kec Tampan Kota Pekanbaru

Tabel 3. Distribusi Frekuensi Pendidikan Responden Kelurahan Tuah Karya dan Sidomulyo Barat di Wilayah Kerja Puskesmas Sidomulyo Kec Tampan Kota Pekanbaru Tahun 2010

\begin{tabular}{cccc}
\hline No & Pendidikan & Jumlah & Persentase \\
\hline 1 & Tidak tamat & 3 & 3,12 \\
\hline 2 & SD & 24 & 25 \\
\hline 3 & SMP & 22 & 22,9 \\
\hline $\mathbf{4}$ & SMA & $\mathbf{3 0}$ & $\mathbf{3 1 , 2 5}$ \\
\hline 5 & SMU & 1 & 1,04 \\
\hline 6 & SMEA & 1 & 1,04 \\
\hline 7 & SPG & 1 & 1,04 \\
\hline 8 & SPA & 1 & 1,04 \\
\hline 9 & SMK & 1 & 1,04 \\
\hline 10 & DIII & 6 & 6,25 \\
\hline 11 & S1 & 6 & 6,25 \\
\hline & Jumlah & 96 & 100 \\
\hline
\end{tabular}

Berdasarkan Tabel 3. Pendidikan responden Kelurahan Tuah Karya dan Sidomulyo Barat di Wilayah Puskesmas Sidomulyo terbanyak adalah berpendidikan SMA ( 31,25\%).

Bersadarkan Penggolongan Perkerjaan

Penggolongan Perkerjaan responden di Kelurahan Tuah Karya dan Sidomulyo Barat di Wilayah Puskesmas Kec Tampan Kota Pekanbaru

Tabel 4. Distribusi Frekuensi Perkerjaan Responden Kelurahan Tuah Karya dan Sidomulyo Barat di Wilayah Kerja Puskesmas Sidomulyo Kec Tampan Kota Pekanbaru Tahun 2010

\begin{tabular}{cccc}
\hline No & Perkerjaan & Jumlah & Persentase \\
\hline 1 & Buruh & 3 & 3,12 \\
\hline 2 & Pedagang & 15 & 15,62 \\
\hline 3 & Buruk Pabrik & 1 & 1,04 \\
\hline 4 & Guru & 6 & 6,25 \\
\hline 5 & Tukang & 1 & 1,04 \\
\hline 6 & Mahasiswa & 2 & 2,08 \\
\hline 7 & Pegawai negeri & 2 & 2,08 \\
\hline 8 & Petani & 2 & 2,08 \\
\hline 9 & Pelajar & 3 & 3,12 \\
\hline 10 & IRT & 61 & 63,54 \\
\hline & Jumlah & 96 & 100 \\
\hline
\end{tabular}

Berdasarkan Tabel 4. Pekerjaan responden Kelurahan Tuah Karya dan Sidomulyo Barat di Wilayah Puskesmas Sidomulyo terbanyak adalah Ibu rumah tanggah $(63,54 \%)$.

Bersadarkan penggolongan Jenis

\section{Kelamin}

Penggolongan Jenis Kelamin responden di Kelurahan Tuah Karya dan Sidomulyo Barat di Wilayah Puskesmas Kec Tampan Kota Pekanbaru

Tabel 5 Distribusi Frekuensi Jenis Kelamin Responden Kelurahan Tuah karya dan Sidomulyo Barat di Wilayah Kerja Puskesmas Sidomulyo Kec Tampan Kota Pekanbaru Tahun 2010

\begin{tabular}{cccc}
\hline No Jenis Kelamin & Jumlah & Persentase \\
\hline 1 & Perempuan & $\mathbf{7 9}$ & $\mathbf{8 2 , 2 8}$ \\
\hline 2 & Laki-laki & 17 & 17,70 \\
\hline 3 & Jumlah & 96 & 100 \\
\hline
\end{tabular}

Berdasarkan Tabel 5. Jenis Kelamin Responden Kelurahan Tuah Karya dan Sidomulyo di Wilayah Puskesmas Sidomulyo terbanyak Perempuan (82,28\%).

Analisi Faktor-faktor Risiko Yang Berhubungan Dengan Diare.

Hubungan Kodisi Kesehatan Lingkungan dengan Diare.

Untuk kondisi air, tidak ada hubungan dengan diare, karena dari hasil uji statistik chisquare dengan continuity correction diperoleh nilai $\mathrm{p}=(0,72)>\alpha=(0,05)$ dengan demikian $\mathrm{p}$ -value lebih besar dari alpha, berarti tidak ada perbedaan yang terkena diare dengan kondisi air yang sehat maupun yang tidak sehat, namun secara presentase responden pada distribusi keadaan air tidak sehat $6,(66,7 \%)$ dan terkena diare 3,(33,3\%). Pada hasil diatas OR yaitu 0,64 (95\% Ci:1,51-27,46), ini berarti kondisi air tidak sehat mempunyai peluang 0,64 untuk terkena diare dibandingkan dengan kondisi air sehat.

Peneliti berpendapat dari hasil di atas dapat ketahui keadaan responden di kelurahan tuah karya dan sidomulyo barat mayoritas responden ibu rumah tanggah 61 atau 63,54\% berumur antara 31-40 berjumlah 33 orang atau 34,37\% hal ini bila dikolerasikan peran ibu sebagai ibu 
rumah tangga untuk penyedian air bersih, lebih tepatnya air untuk di minum; air yang di kosumsi memenuhi syarat standar air bersih di mana air minum tidak berbau tidak ada endapan dan di masak.

Faktor lain yang menyebabkan tidak ada hubungan antara keadaan air dengan diare mungkin disebabkan sumber air minum yang di gunakan berasal dari air gallon, sumur, tidak terkontaminasi dengan bakteri yang dapat menimbulkan diare, sebab lain yang tidak ada hubunganya dengan diare berkemungkinan dalam penelitian ini sampel yang di gunakan sedikit atau ada faktor lain yang belum di ketahui oleh peneliti.

Pembuangan sampah tidak ada hubungan dengan diare, karena dari hasil uji statistik chisquare dengan continuity correction diperoleh nilai $p=(0,66)>\alpha(0,05)$, dengan demikian $p$ value lebih besar dari alpha, berarti tidak ada berpedaan yang

terkena diare dengan pembuangan sampah yang sehat maupun yang tidak sehat, namun secara presentase responden pada distribusi keadaan pembuangan sampah tidak sehat 14 $(63,6 \%)$ dan terkena diare $8(36,4 \%)$. Pada hasil diatas Pada hasil diatas OR yaitu 0,71 (95\% $\mathrm{Ci}: 2,66-18,96)$, ini berarti pembuangan sampah yang tidak sehat mempunyai peluang 0,71 untuk terkena diare dibandingkan dengan kondisi pembuangan sehat.

Peneliti berpendapat dari hasil di atas dapat ketahui keadaan responden di kelurahan tuah karya dan sidomulyo barat tidak adanya hubungan antara pembuangan sampah dengan diare dimana pembungan sampah yang di lakukan diangkut oleh mobil angkutan sampah 2 kali dalam seminggu.

Keadaan tempat pembuangan sampah yang di lakukan responden menjadikanya tempat pembuangan sementara, dalam situasi ini keadaan tempat pembuangan sampah lebih banyak terbuka, ini jelas merupakan risiko untuk terkena diare, dalam penelitian ini hanya mampu mengambarkan secara diskriftif .

Faktor lain yang menyebabkan tidak ada nya hubungan pembungan sampah dengan diare ini keberadaan sampah yang di buang belum sepenuhnya mengalami proses pembusukan di mana mobil angkutan sampah datang tepat waktunya kalaupun mobil sampah tidak datang digantikan dengan mobil yang lain ini jelas

keberadaan sampah yang di buang tidak ada hubunganya dengan diare ini menjadikan lingkungan ini sehat.

Keadaan lingkungan yang sehat/optimum berpengaruh positif terhadap terwujudnya status kesehatan di mana tersedianya tempat pembungan sampah sementara walaupun keberadaanya adanya terbuka atau tertutup dan diangkut oleh mobil sampah keadaan merupakan upaya untuk membuat kesehatan lingkungan lebih baik

Kesehatan lingkungan adalah suatu usaha untuk memperbaiki atau mengoptimumkan lingkungan hidup manusia agar merupakan media yang baik untuk terwujudnya kesehatan yang oktimum bagi manusia yang hidup di dalamnya.(Mark Edberg, 2002)

Sementara faktor lain kemungkinan dari sampel yang di gunakan mungkin tidak cukup , atau ada faktor lain di mana diare yang di timbulkan bisa saja terjadi dari dalam responden itu sendiri, contohnya faktor strees yang berhasal dari dalam individu.

Pembuangan limbah WC tidak ada ada hubungan dengan diare, karena dari hasil uji statistik chi-square dengan continuity correction diperoleh nilai $\mathrm{p}=(1,00)>\alpha=(0,05)$, dengan demikian p-value lebih besar dari alpha, berarti tidak ada perbedaan yang terkena diare dengan pembuangan limbah WC yang sehat maupun yang tidak sehat.

Namun secara presentase responden pada distribusi pembuangan limbah WC tidak sehat $16(57,1 \%)$ dan terkena diare $12(42,9 \%)$ Pada hasil diatas OR yaitu $0,10(95 \% \mathrm{Ci}: 2,66-18,96)$, ini berarti pembuangan limbah WC yang tidak sehat mempunyai peluang 0,10 untuk terkena diare dibandingkan dengan kondisi pembuangan limbah WC sehat.

Peneliti berpendapat dari hasil di atas dapat ketahui keadaan responden di kelurahan tuah karya dan sidomulyo barat tidak adanya hubungan antara Pembuangan limbah WC 
dengan diare ini keberadaan WC responden mengunakan model septic tank

Pengunaan WC model septic tank menenuhui standar kesehatan, dimana keberadaan tertutup, tidak mencemari lingkungan di sekitar,tidak berbau, (Notoatmodjo. 2002).

Hanya saja keberadaan WC ada yang berbau ada yang tidak berbau ini disebabkan kurangnya peratian ibu-ibu untuk membersihkan.

Pengunaan jamban model septic tank merupakan sesuatu program yang dianjurkan oleh pemerinta di kenal dengan jamban sehat, ini jelas tidak adanya hubungan dengan diare, bila di

hubungkan dengan jenis kelamin responden, $82,28 \%$ jenis kelamin perempuan, berumur 31 40 tahun dengan persentase $34,37 \%$ dan perkerjaan sebagian ibu rumah tangga 61 atau dengan persentase $63,54 \%$ keberadaan ibu-ibu muda di sini menurut peneliti masih kurang untuk menjaga kebersihan terutama membersihkan WC sehingga menimbulkan bau, bila keadaan ini berlanjut terus meneus akan menudang keberadaan vektor penyakit dan merupakan risiko untuk terkena diare.

Tabel 6. Distribusi Keadaan Kesehatan Lingkungan dengan Diare di Tuah Karya dan Sidomulyo Barat Wilayah kerja Puskesmas Sidomulyo Kota Pekanbaru

\begin{tabular}{llll}
\hline $\begin{array}{l}\text { NoKesehatan Sehat Diare } \\
\text { lingkungan }\end{array}$ & TotalP.ValueOR 95\% Ci \\
\hline 1.-Sehat 39(57,4\%)29(42,65\%)68 & 1.00 & $\begin{array}{l}0,10 \text { (CL4,14- } \\
24,55)\end{array}$ \\
\hline & &
\end{tabular}

Keadaan kesehatan lingkungan tidak ada hubungan dengan diare karena dari hasil uji statistik chi-square dengan continuity correction diperoleh nilai $\mathrm{p}=(1,00)>\alpha=(0,05)$, dengan demikian $\mathrm{p}$ value lebih besar dari alpha , berarti tidak ada berpedaan yang terkena diare dengan lingkungan sehat maupun lingkungan tidak sehat.

Namun secara presentase responden pada kondisi lingkungan tidak sehat menunjukan 16 $(57,1 \%)$ dan terkena diare 12 (42,9\%) Pada hasil diatas OR yaitu $0,10(95 \% \mathrm{Ci}: 2,66-18,96)$, ini berarti kondisi lingkungan yang tidak sehat mempunyai peluang 0,10 untuk terkena diare dibandingkan dengan kondisi lingkungan sehat.

Peneliti berpendapat dari hasil di atas dapat ketahui keadaan masyarakat di kelurahan tuah karya dan sidomulyo barat mayoritas ibu rumah tanggah 61 atau $63,54 \%$ berumur antara 31- 40 berjumlah 33 orang atau $34,37 \%$ hal ini bila dikolerasikan peran ibu sebagai ibu rumah tangga untuk menciptakan kondisi lingkungan yang sehat.

Keadaan lingkungan yang sehat harus ada tempat pembungan sampah, penyedian air bersih, penyedian jamban/WC, hasil penelitian untuk kondisi lingkungan di tuah karya dan sidomulyo barat keadaan lingkungan yang mencakup; penyedian air, pembuangan sampah, pembungan limbah WC tidak ada hubungannya dengan kejadian diare hal ini terjadi karena bakteri yang menyebabkan terjadinya diare belum dapat menjadikan risiko untuk terinfeksi, di mana air untuk di minum bersumber dari, sumur, gallon sebelum di minum terlebih dahulu di masak.

Tidak adanya hubungan disebabkan mayoritas berusia dewasa ini menjadika daya tahan tubuh yang kuat, namun demikian perlu mendapatkan perhatian ibu -ibu yang mayoritas ibu rumah tanggah di mana keadaan lingkungan yang tidak sehat khususnya pembuangan limbah WC dan tempat pembuangan sampah yang tidak sehat, ini akan menjadikan kecendrungan

Merupakan factor risiko akan terjadinya diare ini akan mempengaruhi status kesehatan.

Menurut pendapat Hendrik 1.blum yang di kutip oleh notoatmodjo (2003) keadaan lingkungan yang sehat/optimum berpengaruh positif terhadap terwujudnya status kesehatan di mana tersedianya air bersih, jamban, tempat pembungan sampah, pembuangan air kotoran. Keadaan usaha kesehatan lingkungan adalah suatu usaha untuk memperbaiki atau mengoptimumkan lingkungan hidup manusia agar merupakan media yang baik untuk terwujudnya kesehatan yang oktimum bagi manusia yang hidup di dalamnya. 
Hubungan Keadaan vektor pembawa penyakit dengan diare

Hubungan antara keadaan vektor lalat, kecoa dan tikus sebagai pembawa penyakit dengan kejadian diare dapat dilihat pada table 7 .

Tabel 7 Distribusi Keadaan Vektor Pembawa Penyakit dengan Diare di Tuah Karya dan Sidomulyo Barat Wilayah kerja Puskesmas Sidomulyo Kota Pekanbaru

\begin{tabular}{llccc}
\hline No Vector Sehat Diare & \multicolumn{1}{c}{ TotalP.ValueOR 95\% Ci } \\
& & & & \\
\hline 1. & -Tidak ada18(58,1\%)13(41,9) & 31 & 1,00 & 0,10 (CL:4,41- \\
-Ada lalat $37(56,9 \%) 28(43,1)$ & 65 & & \\
\hline 2 & -Tidakada $13(59,1 \%) 9(40,9 \%)$ & 22 & 1,00 & 0,11 (CL:4,19- \\
-Ada kecoa42(56,8\%)32(43,2\%)74 & & \\
\hline 3 & -Tidak ada7(53,8\%) $6(46,2)$ & 13 & 0,78 & 0,85 (CL:2,63- \\
& -Ada tikus 48(57,8\%)35(42,2\%)83 & & \\
\hline
\end{tabular}

Berdasarkan tabel 7 dapat dilihat adanya lalat, tidak ada hubungannya dengan diare, karena dari hasil uji statistik chi-

square dengan continuity correction diperoleh nilai $\mathrm{p}=(1,00)>\alpha=(0,05)$.

Namun secara presentase responden, adanya lalat di responden yang sehat $37(56,9 \%)$ menunjukan kasus terkenan diare $28(43,1 \%)$. Pada hasil diatas OR yaitu $0,10(95 \%$ Ci:2,66$18,96)$, ini berarti adanya lalat di responden mempunyai peluang 0,10 untuk terkena diare dibandingkan dengan tidak.

Peneliti berpendapat dalam penelitian ini hanya dapat mengambarkan secara diskriftif dimana tidak adanya hubungan antara vector lalat dengan diare secara statistic disebabkan sampel yang di gunakan sedikit.

Faktor lain keberadaan sampah yang di angkut oleh mobil angkutan sampah 2 kali dalam seminggu yang menjadikan lingkungan tidak berbau.

Keadaan lingkungan yang sehat/optimum berpengaruh positif terhadap terwujudnya status kesehatan di mana tersedianya air bersih, jamban, tempat pembungan sampah, pembuangan air kotoran. Keadaan usaha kesehatan lingkungan adalah suatu usaha untuk memperbaiki atau mengoptimumkan lingkungan hidup manusia agar merupakan media yang baik untuk terwujudnya kesehatan yang oktimum bagi manusia yang hidup di dalamnya.

Pada vektor kecoa tidak ada hubungan dengan diare, karena dari hasil uji statistik chisquare dengan continuity correction diperoleh nilai $\mathrm{p}=(1,00)>\alpha=(0,05)$, dengan demikian $\mathrm{p}$ value lebih besar dari alpha, berarti tidak ada berpedaan yang terkena diare dengan adanya kecoa maupun yang tidak ada kecoa,

Namun secara presentase responden pada distribusi keadaan adanya kecoa $42(56,8 \%)$ dan terkena diare $32(43,2 \%)$ Pada hasil diatas OR yaitu $0,11(95 \% \mathrm{Ci}: 2,66-18,96)$, ini berarti ada kecoa di responden yang sehat mempunyai peluang 0,11 untuk terkena diare dibandingkan dengan tidak ada kecoa

Pada tikus tidak ada hubungan dengan diare, karena dari hasil uji statistik chi-square dengan continuity correction diperoleh nilai $\mathrm{p}=(0,78)>$ $\alpha(0,05)$, dengan demikian $p$ value lebih besar dari alpha $(5 \%)$, berarti tidak ada berpedaan yang terkena diare dengan adanya tikus maupun yang tidak ada tikus,

Namun secara presentase responden pada distribusi keadaa adanya tikus $48(57,8 \%)$ dan terkena diare $35(42,2 \%)$, Pada hasil diatas OR yaitu 0,85 (95\% Ci:2,63-27,53), ini berarti ada tikus di responden sehat mempunyai peluang 0,85 untuk terkena diare dibandingkan dengan kondisi yang tidak ada tikus.

Tabel 8. Distribusi Keadaan vektor dengan Diare di Tuah Karya dan Sidomulyo Barat Wilayah kerja Puskesmas Sidomulyo Kota Pekanbaru

\begin{tabular}{|c|c|}
\hline $\begin{array}{l}\text { No KesehatanSehat } \\
\text { lingkungan }\end{array}$ & TotalP.Value OR 95\% Ci \\
\hline $2(50 \%) \quad 2(50 \%)$ & $\begin{array}{r}0,76(\mathrm{Ci} 0,99- \\
54.54)\end{array}$ \\
\hline $53(57,6 \%) 39(42,4 \%)$ & 92 \\
\hline
\end{tabular}

Keadaan vektor tidak ada hubungan dengan diare karena dari hasil uji statistik chi-square dengan continuity correction diperoleh nilai $\mathrm{p}=(1,00)>\alpha(0,05)$, dengan demikian $\mathrm{p}$ value lebih besar dari alpha, berarti tidak ada berpedaan yang terkena diare dengan yang ada vector maupun yang tidak ada vector, 
Namun secara presentase responden pada kondisi ada vector $53(57,6 \%)$ dan terkena diare $39(42,2 \%)$ Pada hasil diatas OR yaitu 0,76 (95\% Ci:2,66-18,96), ini berarti ada vector mempunyai peluang 0,76 untuk terkena diare dibandingkan dengan tidak ada vector .

Menurut peneliti tidak adanya hubungan vector pembawa penyakit dengan diare dari hasil diatas dapat ketahui bahwa keadaan responden di kelurahan tuah karya dan sidomulyo barat di sebabkan ada faktor lain belum peneliti ketahui hal ini merupakan kecendrungan untuk risiko terkena diare ini bisa saja terjadi.

Keberadaan dari sisa-sisa makanan, minuman, bila tidak di bersihkan mengundang berbagai vector pembawah penyakit seperti; tikus, kecoa, atau lalat hal ini di sebabkan keberadaan vector untuk mencari makanan dari sisa makanan yang tidak di bersihkan.

Peran ibu rumah tanggah apalagi tergolong ibu-ibu muda peranya sangat diperlukan dimana vector pembawa penyakit (diare) seperti kecoa, tikus, lalat ; ini perlu pengendaliannya; seperti ; tempat pembuangan sampah tidak tertutup harus di upayakan tertutup atau sisa makan tidak dibersihkan di upayakan di bersihkan, sampah diletakan pada tempat sampah sementara dan diangkut oleh mobil sampah hal ini merupakan upaya mengurangi keberadaan lalat di mana menjadikan lingkungannya tidak berbau, menjadikan tidak adanya hubungan dengan diare, keadaan WC yang diupayakan dibersihkan akan mengurangi keberadaan kecoa dan tempat yang terbuka memungkinkan sinar matahari dapat masuk akan dapat mengurangi keberadaan kecoa di mana keadaan lingkungannya kering memungkinkan mengurangi keberadaan kecoa.

Faktor lain yang menjadikan tidak ada hubungan vector dengan diare, daya tahan tubuh responden di mana umur responden berusia $31-40$ th ; 34,37\% ini memungkinkan daya tahan tubuh yang kuat.

Menurut pendapat Neely, 2005 Sanitasi lingkungan yang tidak sehat dalam pengelolaan sampah, limbah cair, termasuk tinja dan sanitasi rumah dapat mengudang kehadiran vektor pembawa penyakit diantaranya, kecoa, tikus, dan lalat,hal ini merupak risiko untuk terkena penyakit.

\section{Hubungan Hygiene perorangan dengan diare}

Hubungan Hygiene yang meliputi cuci tangan sebelum makan,cuci tangan setelah aktivitas, potong kuku dengan kejadian diare dapat dilihat pada table 9 .

Tabel 9. Distribusi Hubungan Hygiene perorangan dengan diare di Tuan Karya dan Sidomulyo Barat Wilayah kerja Puskesmas Sidomulyo Kota Pekanbaru.

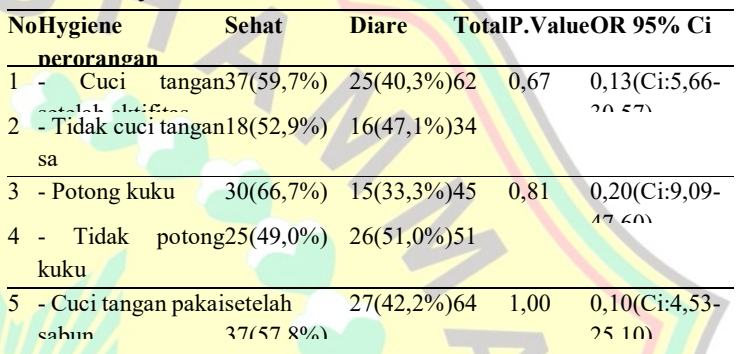

Berdasarkan tabel 9 dapat dilihat bahwa, tidak ada hubungan antara cuci tangan setelah aktivitas maupun sebelum aktifitas dengan diare, karena dari hasil uji statistik chi-square dengan continuity correction diperoleh nilai $p=0,67>\alpha=(0,05)$, namun secara presentase responden yang tidak mencuci tanggan setelah aktifitas $18(52,9 \%)$ dan terkena diare $16(47,1 \%)$ Pada hasil diatas OR yaitu 0,13 (95\% Ci:5,66-30,57), ini berarti tidak mencuci tangan setelah aktifitas mempunyai peluang 0,13 untuk terkena diare dibandingkan dengan tidak mencuci tangan.

Untuk memotong kuku, tidak ada hubungannya dengan diare, karena dari hasil uji statistik chi-square dengan continuity correction diperoleh nilai $(0,81)>\alpha(0,05)$. Namun secara presentase responden yang tidak memotong kuku 25(49,0\%) dan terkena diare $26(51,0 \%)$.Pada hasil diatas OR yaitu 0,20 (95\% Ci: 9,09-47,60) ini berarti tidak memotong kuku mempunyai peluang 0,20 untuk terkena diare dibandingkan dengan tidak mencuci tangan.

Peneliti berpendapat bila di hubungkan dengan jenis kelamin responden mayoritas perempuan dengan $28,82 \%$. Kebiasaan wanita 
pada umumnya tidak teraturnya memotong kuku di karenakan untuk kecantikan, perawatan yang di lakukan hanya memotong bagian bagian tertentu. Ini satu diantaranya yang menyebabkan tidak adanya hubungan memotong kuku dengan diare

Tidak ada hubungannya antara memotong kuku dengan diare kemungkinan dari sampel responden yang di gunakan sedikit, dan ini hanya dapat mengambarkan secara diskriftif.

Mencuci tangan pakai sabun setelah beraktivitas, tidak ada hubungannya dengan diare, karena dari hasil uji statistik chi-square dengan continuity correction diperoleh nilai $\mathrm{p}=$ $(1,00)>\alpha=(0,05)$. namun secara presentase responden yang tidak mencuci tanggan setelah aktifitas $18(56,2 \%)$ dan terkena diare 14(43,8\%). Pada hasil diatas OR yaitu 0,13 (95\% Ci: 9,09-47,60), ini berarti tidak mencuci tangan setelah aktifitas mempunyai peluang 0,13 untuk terkena diare dibandingkan dengan tidak mencuci tangan.

Peneliti berpendapat dari hasil penelitian hanya dapat mengambarkan secara diskriftif. Di mana mecuci tanggan mengunakan sabun setelah buang air besar ada yang dilakukan responden ada yang tidak, tidak dilakukan responden mengunakan sabun bukan berarti harus diare.Tidak ada hubungannya antara kebiasaan buanga air besar mengunakan sabun dengan diare dalam penelitian ini sebabkan jenis WC yang memenuhi standar kesehatan.

Kebiasaan buang air besar mengunakan sabun hanya menjadikan kebiasan responden untuk hidup bersih dan mengurangi risiko untuk terkena diare. Hal ini bila di hubungkan dengan peran responden yang mayoritas perempuan dalam hal ini ibu rumah tangah harus mencontohkan kepada anak-anaknya untuk hidup sehat hal ini di dapat dari pengelaman hidup dan informasi yang didapatkan responden.

Tabel 10. Distribusi Hygiene perorangan dengan diare di Tuah Karya dan Sidomulyo Barat Wilayah kerja Puskesmas Sidomulyo Kota Pekanbaru

\begin{tabular}{|l|l|l|l|l|l|}
\hline No & $\begin{array}{l}\text { Hygiene } \\
\text { Perorangan }\end{array}$ & Sehat & Diare & Total P.Value & OR 95\% Ci \\
\hline
\end{tabular}

\begin{tabular}{|l|l|l|l|l|l|}
\hline 1 & -Bersih & $18(62,1 \%)$ & $11(39,9 \%)$ & 290,69 & $\begin{array}{l}0,13(\mathrm{Ci}: 5,44- \\
33,35)\end{array}$ \\
\hline 2 & $\begin{array}{l}\text {-Tidak } \\
\text { bersih }\end{array}$ & $37(55,2 \%)$ & $30(44,8 \%)$ & 67 & \\
\hline
\end{tabular}

Berdasarkan tabel 10. dapat dilihat bahwa, tidak ada hubungan antara hygiene perorangan dengan diare, karena dari hasil uji statistik chisquare dengan continuity correction diperoleh nilai $\mathrm{p}=(0,69)>\alpha=(0,05)$, namun secara presentase responden yang tidak bersih $37(55,2 \%)$ dan terkena diare 30(44,8\%) .Pada hasil diatas OR yaitu 0,13 (95\% Ci: 5,44-33,35), ini berarti tidak bersih mempunyai peluang 0,13 untuk terkena diare dibandingkan dengan bersih.

Menurut analisi peneliti tidak adanya hubungan; cuci tangan setelah aktivitas, potong kuku, cuci tangan pakai sabun tidak ada hubungan dengan diare ini bisa saja terjadi, di mana faktor lain yang menyebabkan ditinjau dari umur responden antara 31-40 berjumlah $34,37 \%$ di usia ini responden tergolong kuat, cukup istirahat dan olah raga.

Daya tahan tubuh yang kuat akan mampu mengurangi risiko untuk terkena diare, diare sebenarnya akan hilang dengan sendirinya dengan perbaikan hygiene perorangan, upaya pencegahan terjadinya penyakit diare pada orang dewasa, adalah personel hygiene, mencuci tangan kebiasaan yang berhubungan dengan kebersihan perseorangan yang penting dalam penularan diare. Mencuci tangan dengan sabun, terutama setelah buang air besar, sesudah membuang tinja anak, sebelum menyiapkan makanan, sebelum menyuapi makanan anak, mempunyai dampak dalam kejadian diare dalam penurunan risiko terhadap penyakit diare.

WHO menyatakan bahwa lebih dari sepertiga kematian anak secara global disebabkan karena diare (35\%).Kebiasaan Cuci tangan pakai sabun bisa menurunkan kejadian penyakit diare sebanyak $45 \%$. UNICEF memperkirakan bahwa secara global diare menyebabkan kematian satu anak setiap 30 detik. (Abahjack, 2010) 
Hubungan Kebiasan jajan dengan diare

Hubungan Kebiasan Jajan dengan kejadian diare dapat dilihat pada table 11 .

Tabel 11. Distribusi Jajan Pinggir Jalan dengan Diare di Tuah Karya dan Sidomulyo Barat Wilayah kerja Puskesmas Sidomulyo Kota Pekanbaru.

\begin{tabular}{|c|c|c|c|c|}
\hline Jajan di pinggir jalan & Sehat & Diare & Total P.Value & OR 95\% Ci \\
\hline Tidak jajan di pj & $28(57,1 \%)$ & $21,(42,9 \%)$ & 491,00 & $0,98($ Ci: $4,40-22,18$ \\
\hline Jajan di pj & $27(57,4 \%)$ & $20(42,6 \%)$ & 47 & \\
\hline
\end{tabular}

Berdasarkan tabel 11. dapat dilihat bahwa, tidak ada hubungan antara jajan di pinggir jalan dengan diare, karena dari hasil uji statistik chisquare dengan continuity correction diperoleh nilai $(1,00)>\alpha(\mathrm{p}=0,05)$, namun secara presentase responden yang jajan di pinggir jalan $27(57,4 \%)$ dan terkena diare 20(42,6\%). Pada hasil diatas OR yaitu 0,98 (95\% Ci: 4,40-22,18), ini berarti jajan mempunyai peluang 0,98 untuk terkena diare dibandingkan dengan tidak jajan di pinggir jalan.

Tabel 12. Distribusi Makan di Pinggiran /Rumah Makan dengan diare di Tuah Karya dan Sidomulyo Barat Wilayah kerja Puskesmas Sidomulyo Kota Pekanbaru

\begin{tabular}{|c|c|c|c|}
\hline No & $\begin{array}{cc}\text { Makan } & \text { Sehat } \\
\text { diPinggiran/Rumah } & \end{array}$ & Diare TotalP.Value & OR $95 \% \mathrm{Ci}$ \\
\hline 1 & - Tidak makan di P/R 20(58,8\% & 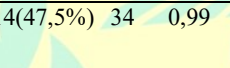 & $\begin{array}{c}0,11(\mathrm{Ci}: 4,72- \\
25,72)\end{array}$ \\
\hline
\end{tabular}

Berdasarkan tabel 12. dapat dilihat bahwa, tidak ada hubungan antara Makan di pinggiran /rumah makan dengan diare, karena dari hasil uji statistik chi-square dengan continuity correction diperoleh nilai $0,99>\alpha(0,05)$. Namun secara prosentase adanya makan dipinggiran atau rumah makan 35(56,5\%) pada responden sehat, kasus terkena diare $27(43,5 \%)$ hasil diatas OR yaitu 0,11 (95\% Ci: 4,72-25,72), ini berarti jajan mempunyai peluang 0,11 untuk terkena diare dibandingkan dengan tidak jajan di pinggir jalan.

Peneliti menganalisa sesuai dengan data yang ada tidak adanya hubungan kebiasaan jajan di pinggir jalan dengan kejadian diare yang terjadi di wilayah kerja puskesmas sidomulyo khususnya di kelurahan sidomulyo barat dan tuah karya ini bisa saja terjadi dan masih merupakan risiko untuk terjadi bila makanan yang di jual tidak terkontaminasi dengan bakteri yang dibawah oleh vektor penyakit di mana dalam pengolahan makanan cara mencuci menyimpat dan menjualnya dalam keadaan bersih, atau sebaliknya pengolahan makanan yang tidak bersih berrisiko untuk terkena diare.

Kebiasaan makan dipinggiran jalan atau diluar rumah perlu berhati-hati terutama ke responden berjenis kelamin perempuan $82,28 \%$ dan $63,54 \%$ ibu-ibu haruslah mememili makanan dan minuman dalam keadaan tertutup agar terindar dari diare, ini sifat dari ibu-ibu yang terkadang kurang memperhatikan keadaan kebersihan makanan.

Menurut Hasan, 2008 akan menguraikan penyakit-penyakit yang bisa diderita akibat jajan di tempat yang tidak bersih, penyakit akibat salah makan itu dibagi menurut penyebabnya. Sedikitnya ada empat penyebab penyakit tersebut seperti bakteri (tifus, muntaber), virus (hepatitis), parasit (cacing) dan bumbu penyedap (MSG).

Khusus untuk penyakit tifus dibagi lagi atas dua jenis yaitu demam tifoid, dan paratifus yang biasanya gejalanya lebih ringan. "Yang paling ditakutkan karena kefatalan (bisa menyebabkan kematian) dari penyakit ini adalah perforasi (bolongnya) gejala ini, katanya, biasa terjadi pada minggu kedua jika tanpa pengobatan yang adekuat. gejalanya, sebelumnya penderita menderita panas yang secara bertangga naiknya, makin hari makin suhu tubuh meningkat dan hanya bisa diturunkan sebentar oleh obat penurun panas.

\section{Hubungan Pelayanan Kesehatan dengan} diare

Hubungan Pelayanan Kesehatan dengan kejadian diare dapat dilihat pada table 5.3

Tabel 13. Distribusi Pelayanan Kesehatan dengan diare di Tuah Karya dan Sidomulyo Barat Wilayah kerja Puskesmas Sidomulyo Kota Pekanbaru

\begin{tabular}{|c|c|c|c|c|c|}
\hline$\overline{\text { No }}$ & $\begin{array}{ll}\text { Pelayanan } & \text { Sehat } \\
\text { Kesehatan } & \end{array}$ & Diare & Total & P.Value & OR $95 \% \mathrm{Ci}$ \\
\hline$\overline{1}$ & $\begin{array}{l}- \text { Mendapat32(53,3\%) } \\
\text { penyuluhan }\end{array}$ & $28(46,7 \%)$ & 60 & 0,42 & $\begin{array}{l}0,64(\mathrm{CL}: 2,77- \\
15,09)\end{array}$ \\
\hline 2 & $\begin{array}{l}\text { - Tidak23(63,9\%) } \\
\text { mendapat Pel }\end{array}$ & $13(36,1 \%)$ & 36 & & \\
\hline
\end{tabular}




\begin{tabular}{llllll}
\hline No & $\begin{array}{l}\text { Pelayanan Sehat } \\
\text { Kesehatan }\end{array}$ & Diare & Total & P.Value & OR 95\% Ci \\
\hline 3 & $\begin{array}{l}\text { - Didatangi21(52,5\%) } \\
\text { Petugas }\end{array}$ & $19(47,5 \%)$ & 40 & 0,55 & $0,71(\mathrm{CL}: 3,15-$ \\
4 & $-\quad$ Tidak34(60,7\%) & $22(39,3)$ & 56 & & $16,24)$ \\
& didatagi
\end{tabular}

Berdasarkan tabel 13. dapat dilihat bahwa, tidak ada hubungan antara mendapat penyuluhan dan tidak mendapat penyuluhan dengan diare, karena dari hasil uji statistik chisquare dengan continuity correction diperoleh nilai $\mathrm{p}=(0,42)>\alpha(=0,05)$. Namun secara presentase tidak dapat penyuluhan pada responden sehat $23(63,9 \%)$ dan kasus diare 13(36,1\%). Pada hasil diatas OR yaitu 0,64 (95\% Ci: 2,77-15,09), ini berarti tidak mendapat penyuluhan kesehatan mempunyai peluang 0,64 untuk terkena diare dibandingkan dengan mendapat penyuluhan kesehatan.

Untuk yang pelayanan kesehatan (yang didatangi petugas,tidak didatangi petugas tidak ada hubungannya dengan diare karena dari hasil uji statistik chi-square dengan continuity correction diperoleh nilai $\mathrm{p}=(0,55)>\alpha(0,05)$. Namun secara presentase tidak di datangi petugas pada responden sehat $34(60,7 \%)$ dan kasus diare $22(39,1 \%)$. Pada hasil diatas OR yaitu $0,71(95 \% \mathrm{Ci}: 3,15-16,24)$, ini berarti tidak didatangi petugas mempunyai peluang 0,71 untuk terkena diare dibandingkan dengan tidak didatangi petugas kesehatan.

Menurut peneliti hal ini jelas merupakan risiko dalam pelayanan kesehatan untuk terkena diare di mana keterangan atau informasi yang diperlukan responden berguna untuk menghindari terjadinya diare. untuk ini puskesmas harus memberikan keterangan tentang keberadaan diare dalam memberikan layanan kesehatan dan apa yang di lakukan bila terjadi diare puskesmas harus memperbaiki keadaanya yang harus diperhatikan antara lain konsep kinerja, waktu yang ada untuk memberikan keterangan tentang diare, standard kerja, konsep pendekatan sisitem, dan substansi yang dibahas dalam konsep-konsep mutu tersebut,

dimana kosep-konsep tersebut saling terkait. Mutu pelayanan kesehatan termasuk mutu adalah pelayanan kesehatan yang dapat memenuhi kebutuhan pasien serta tata cara pelaksanaan sesuai dengan kode etik dan standard profesi yang telah ditetapkan.

Penelitian sugeng 2008, diketahui bahwa mutu pelayanan kesehatan termasuk hanya dapat diketahui apabila sebalumnya telah dilakukan penilaian terhadap kinerja, hasil penilaian itu dibandingkan dengan standard tertentu, karena itu mutu memiliki kaitan yang erat dengan kinerja dan standard.

Menurut Usman 2009, pelayanan kesehatan terhadap pasien penderita diare berlangsung cepat dan tepat sesuai dengan prosedur yang ada dan kita akan tetap memberikan cairan infuse nacl bila ada warga yang menceretmencert.pelayanan yang di berikan merupakan prioritas terutama kepada anak -anak hal ini di lakukan untuk mencukupi akan cairan tubuh yang hilang .

\section{KESIMPULAN DAN SARAN}

Berdasarkan hasil dan pembahasan, maka dapat diambil beberapa kesimpulan dan saran sebagai berikut :

\section{Kesimpulan}

Keadaan kesehatan lingkungan tidak ada hubungan dengan diare karena dari hasil uji statistik chi-square dengan continuity correction diperoleh nilai $(1,00)>\alpha(0,05)$ vector pembawa penyakit tidak ada hubungan dengan diare karena dari hasil uji statistik chisquare dengan continuity correction diperoleh nilai $(1,00)>\alpha(0,05)$, tidak ada hubungan antara hygiene perorangan dengan diare, karena dari hasil uji statistik chi- square dengan continuity correction diperoleh nilai $(0,69)>\alpha$ $(0,05)$, tidak ada hubungan antara jajan di pinggir jalan dengan diare, karena dari hasil uji statistik chi-square dengan continuity correction diperoleh nilai $\mathrm{p}=(1,00)>\alpha(0,05)$, tidak ada hubungan antara mendapat penyuluhan dengan diare, karena dari hasil uji statistik chi-square dengan continuity correction diperoleh nilai $\mathrm{p}=(0,42)>\alpha(0,05)$

Hasil ini walaupun tidak terdapat hubungan akan tetapi merupakan masih merupakan risiko untuk akan terjadi diare,dan untuk pelayanan kesehatan ada hubungannya dengan diare disarankan untuk memberikan informasi 
tentang diare yang di butuhkan responden sebagai upaya promotif dan preventif.

Keadaan usaha kesehatan lingkungan adalah suatu usaha untuk memperbaiki atau mengoptimumkan lingkungan hidup manusia agar merupakan media yang baik untuk terwujudnya kesehatan yang oktimum bagi manusia yang hidup di dalamnya

\section{Saran}

a. Perlu mewaspadai keadaan perubahanperubahan keadaan lingkungan itu sendiri seperti banjir, air yang tergenang dan kebiasan mencuci tangan sebelum dan sesudah beraktivitas yang merupakan risiko untuk terjadi diare

b. Kepada puskesmas melalui dinas kesehatan, peneliti manyarankan agar dilakukan penyuluhan tentang keadaan lingkungan kepada masyarakat dengan sasaran ibu rumah tangga.

c. Strategi yang digunakan dapat berupa penyuluhan perorangan oleh bidan dan perawat ketika di adakan posyandu.

\section{DAFTAR PUSTAKA}

Abuddin.2009. Asuhan keperawatan pada anak dengan typhoid http://abuddin.blog.co.uk/2009/01/30/asuha n-keperawatan-pada-anak- denganthyphoid-5472928/di peroleh 26 Mei 2010.

Anonim. 2010 Sistem Daya Tahan http://www.prostar.gov.my/fakta_tahan BM.htm di peroleh tgl 24 Mai 2010.

Anonim. 2010. Infeksi Salmonella Bagaimana Salmonella Tertular Pada ManusiaManusia.

http://www.totalkesehatananda.com/salmon ellainfection2.html di peroleh Tgl 29 Mei 2010.

Amira Mehnaaz. 2009. Kenalkan Tifus Abdominalis. http://www.gaulislam.com/ kenalkan-tifus-abdominalis-2 di peroleh 26 Mei 2010.

Abahjack, 2010 Cuci Tangan Mencegah Penyakit http://abahjack.com/cucitanganmencegah-penyakit.html\#more-3 di 16 okvober 2010
Aziz, 2006 Ilmu Penyakit Dalam Bandung : PT. Citra Aditya Bakti.

Berita Kedokteran Masyarakat. 2007. Vol 23 No.3 September Falkultas kedokteran UGM Yogyakarta.

Budhi Soesilo. 2008. Kecoa (Lipas) dan Pengendaliannya. Catatan Kuliah II. Eman 2006 Diare di Alor, 2 tewas http://www.gizi.net/cgi-

bin/berita/fullnews.cgi?newsid1161322602,4982 $\underline{6}$, di peroleh 16 Oktober 2010

Herman, 2008 Kejadian Diare di Masayarakat http ://puskesmassungkai. wordpress.com/2009/07/21/kemarau-awasdiare-mengancam/ di peroleh 16 oktober 2010

Depkes. 2008. Pedoman Tehnis Pengendalian Lalat. http://www.depkes.go.id/ downloads/Pengendalian\%20Lalat.pdf di peroleh 31 Mei 2010

Gupte, S. 1990. Mikrobiologi Dasar. Alih bahasa Julius ES. Binarupa Aksara.

Edisi III. Hasan, dkk. 2005. Ilmu Kesehatan Anak. Jilid 2. Jakarta : Infomedika.

Hastari Wuryastuti. 2008. Lalat Sebagai Penyebar Berbagai Penyakit Kepada Manusia. Yogyakarta Universitas Gadjah Mada.

Hasan irsan 2008 JAKARTA mandiri, http://www.mailarchive.com/dokter@itb.ac.id/msg04691.ht ml di 17 oktover 2010

Hembing Wijayakusuma. 2005. Mencegah dan Mengatasi Penyakit Pada Musim Pancaroba.http://kotakediri.2.forumer.com/ a/mencegah-amp-mengatasi- penyakit-pdmusim-pancaroba post137.html di peroleh 20 Mei 2010.

Hidayat, P. 2005. Pengenalan Ordo dan Beberapa Famili Serta Anggota Spesiesnya. Bandung : PT. Citra Aditya Bakti.

Iftitah Nafika. 2008. Vektor Penyakit dan Pengendaliannya.di peroleh 21 Mei 2010.

Indah Entjang. 2000. Ilmu Kesehatan Masyarakat. Bandung : PT. Citra Aditya Bakti.

Iswaranti, Widjajarta. 2007. Jajanan di Indonesia Berkualitas

Buruk. 
http://www.republika.co.id. diperoleh 26 Mei 2010.

Juli Soemirat Slamet. 2004. Ilmu Kesehatan Lingkungan. Yogyakarta: Gadjah Mada University Press.

Maulina Desy Aryatie. Pentingnya Pemeliharaan Kebersihan dan Kesehatan atas dari Vektor Kecoa. http://www.logindu.com. diperoleh 26 April 2010.

Mark Edberg, 2002 Kesehatan masyarakat teori social dan perilaku,Buku Kedokteraan EGC.

Mansjoer, Arif., et all. (1999). Kapita Selekta Kedokteran. Jakarta : Fakultas Kedokteran UI.

Nasrul Effendy. 2003. Dasar-Dasar Keperawatan Kesehatan Masyarakat. Jakarta

: Buku Kedokteran EGC.

Notoatmodjo. 2002. Metodologi Penelitian Kesehatan. Jakarta : Rineka Cipta.

2002. Kesehatan masyarakat ilmu dan seni ; Jakarta : Rineka Cipta.
Solihin P. 2005. Ilmu Gizi Pada Anak. Fakultas Kedokteran Universitas Indonesia, Jakarta.

Suparyanto, 2008 jaminan mutu dan manajemen pelayanan kesehatan Jakarta : Rineka Cipta Sutanto P.H ,2001 Modul Analisis Data,Fakultas Kesehatan Masyarakat Universitas Indonesia.

Titik Kuntari, 2008. Rehidrasi, Tindakan Penting Atasi Diarehttp://abahjack.com/cuci-tanganmencegah-penyakit.html\#more-3. diperoleh 16 Juli 2010.

Usman, 2009 Cara menga Kesehatan mutu pelayanan Petugas kesehatan dalam memberikan pelayanan, http://www.lintasberita.com di peroleh 17 Juli 2010 